\title{
STUDI BIOLOGI HAMA KUTU PUTIH PEPAYA Paracoccus marginatus Williams \& Granara de Willink (Hemiptera: Pseudococadea)
}

\author{
Gregorius O Leta ${ }^{1}$, Yustina M.S.W. Pu'u ${ }^{2}$,Imaculata Fatima ${ }^{3}$ \\ Program Studi Agroteknologi, Fakultas Pertanian Universitas Flores \\ george_leta@yahoo.com
}

\begin{abstract}
The goal of this research was to understand the biology of $P$. marginatus, a common pest for papaya plants. This research used 1 type of treatment which was repeated 10 times. The results of this research were intended to illustrate the average development time of each development phase of $P$. marginatus. These phases were: the egg phase (6 days), the female nymph phase (10 days), the male nymph hase (17 days), female adult stage (11 days), male adult stage ( 3 days). On average, the female life cycle was 27 days, and the male life cycle was 26 days. On average, the pre-fertile stage lasted 4 days, the fertile stage lasted 6 days and the post fertile stage lasted 1 day. On average the pre egg-laying adult stage lasted 4 days, the egg-laying adult stage lasted 6 days and the post egg-laying stage lasted 1 day. After the egg laying stage, the average fecundity of P. marginatus was 370 eggs per female and from these, a total of 350 offspring were hatched per individual. The ratio of surviving descendents to reproductive couples of $P$. marginatus white lice was 9:1.
\end{abstract}

Key words: biotechnology, Paracoccus marginatus, white papaya lice.

\section{PENDAHULUAN}

Tanaman pepaya (Carica papaya L.) merupakan salah satu tanaman buahbuahan yang populer di Indonesia. Biji, daun, batang, dan akarnya sangat bermanfaat sebagai obat. Buah pepaya matang sangat unggul dalam hal betakaroten (276 mikrogram/100 g), betacryptoxanthin (761 mikrogram/100 g), serta lutein dan zeaxanthin (75 mikrogram $/ 100 \quad$ g). Betakaroten merupakan provitamin A sekaligus antioksidan yang sangat ampuh untuk menangkal serangan radikal bebas. Vitamin A yang diperoleh dari $100 \mathrm{~g}$ buah pepaya matang berkisar antara
1.094-18.250 SI, tergantung dari varietasnya (Sobir, 2009).

Kabupaten Ende merupakan salah satu daerah yang membudidayakan tanaman pepaya baik untuk komersial maupun konsumsi. Data produksi pepaya Kabupaten Ende tahun 2011 sebesar 54.960 kwintal, dengan luas areal pertanaman pepaya 1.200 ha (Dinas Pertanian Tanaman Pangan dan Peternakan Kabupaten Ende, 2011). Tanaman pepaya banyak dibudidayakan walaupun tidak dalam hamparan luas, tetapi ditumpangsari dengan tanaman lain. Salah satu permasalahan yang dihadapi dalam budidaya tanaman pepaya adalah serangan hama. Salah satu hama 
yang paling sering menyerang tanaman pepaya adalah hama Paracoccus marginatus. Intensitas kerusakan yang disebabkan oleh hama $P$. marginatus di Kabupaten Ende sebesar $25 \%$ yang terdapat pada 2 kecamatan yaitu Kecamatan Ende Timur sebesar 33,33 \% dan Kecamatan Ndona sebesar 16,67 \%. Intensitas serangan tersebut masih tergolong kerusakan sedang dan ringan (Pu'u dan Wahyuni, 2011). Ada beberapa hama lain yang juga menyerang tanaman pepaya seperti kutu sisik, kutu aphids, tungau, ataupun lalat buah yang sering membuat buah pepaya menjadi busuk (Sobir, 2009).

Hama kutu putih biasanya bergerombol sampai puluhan ekor. Mereka merusak tanaman dengan cara mengisap cairan semua bagian tanaman yang diserangnya, dari buah sampai pucuk. Serangan pada pucuk menyebabkan daun kerdil dan keriput seperti terbakar. Hama ini juga menghasilkan embun madu yang kemudian ditumbuhi cendawan jelaga, sehingga permukaan tanaman yang terserang berwarna hitam. Serangan yang hebat ditandai dengan seluruh permukaan bawah daun pepaya yang penuh ditutupi kutu putih (Sobir, 2009).

Siklus hidup hama kutu putih Paracoccus marginatus yaitu rata-rata lama stadium telur adalah 11 hari, lamanya stadia nimfa instar satu 6 hari, stadia nimfa instar kedua 9 hari, instar ketiga 6 hari untuk betina sedangkan 3 hari untuk jantan. Stadia nimfa instar empat untuk jantan 4 hari. Untuk stadia imago betina 21 hari sedangkan jantan 2 hari. Jumlah peletakan telur 100 hingga 600 butirselama satu hingga dua minggu. Suhu optimum bagi perkembangan Paracoccus marginatus yaitu sekitar 35 ${ }^{0} \mathrm{C}$ dengan lokasi penelitian sebelumnya di Florida USA pada tahun 2008 (Amarasekare, et al., 2008).

Penelitian tentang biologi atau siklus hidup hama Paracoccus marginatus membutuhkan waktu \pm 25 hari untuk berkembang dari telur menjadi imago (serangga dewasa). Biologi setiap jenis hama tergantung pada kondisi ekologi di mana tempat hama tersebut berada. Untuk itu perlu dilakukan penelitian "Studi Biologi Hama Kutu Putih Pepaya Paracoccus marginatus Williams \& Granara de Willink (Hemiptera: Pseudococadea)" di Kabupaten Ende.

\section{METODE PENELITIAN}

Penelitian dilaksanakan di Kelurahan Onekore, Kabupaten Ende. Pelaksanaan penelitian dilaksanakan selama 9 bulan, yaitu mulai dari bulan Mei 2011 sampai September 2011. Bahan yang digunakan antara lain adalah tanaman pepaya (Carica papaya L) dan Imago kutu putih pepaya Paracoccus marginatusketurunan F2. Alat yang digunakan antara lain adalah kurungan serangga yang terbuat dari kain kasa, kaca pembesar, kuas, nampan semai dan polybag.

Pelaksanaan penelitian meliputi :

1. Persiapan tanaman inang $P$.

Benih tanaman pepaya ditanam dalam nampan semai dengan menggunakan tanah kompos. Setelah tanaman berumur 30 HST, tanaman dipindahkan ke dalam polybag berukuran $25 \times 25 \mathrm{~cm}$ dengan media tanam berupa tanah dan pupuk kandang $1: 1$. Tanaman dapat digunakan sebagai inang setelah tanaman berumur sekitar 4 bulan atau tinggi tanaman sekitar 40 cm.Penggunaan tanaman pepaya pada umur tersebut dikarenakan belum memiliki akar yang banyak sehingga tidak merusak polybag, namun 
ukuran dan jumlah helai daunnya sudah mampu menyediakan suplai makanan bagi hama $P$. marginatus sampai masa penelitian selesai.

\section{Perbanyakan (Rearing)Paracoccus marginatus}

Beberapa nimfa $P$. marginatus diperoleh dari lapangan yang diambil dari Kecamatan Ndona, kemudian diperbanyak pada tanaman pepaya di tempat penelitian yang dikurung dengan menggunakan kurungan serangga berbentuk kotak berukuran $100 \times 50 \mathrm{~cm}$ berbahan kayu dan kain kasa. Serangga kutu putih yang digunakan sebagai bahan penelitian merupakan serangga generasi kedua (F2). Prosedur perbanyakan P.marginatus

3. Pengamatan Biologi P. marginatus

Pengamatan biologi $P$. marginatus dilakukan di dalam ruangan penelitian. Pengamatan kutu putih pepaya dimulai pada stadium nimfa/naiad instar pertama yang digunakan berada dalam keadaan umur yang sama dan berasal dari beberapa imago. Setiap serangga nimfa/naiad instar pertama diletakkan pada permukaan bagian bawah daun pepaya, kemudian tanaman pepaya dikurung dengan menggunakan kurungan serangga. Jumlah ulangan keseluruhan sebanyak 10 kali ulangan. Pengamatan dilakukan setiap 24 jam sekali dengan menggunakan kaca pembesar.

Peubah biologi yang diamati meliputi:

1. Siklus hidup (hari)

Pengamatan dilakukan dengan cara menghitung jumlah hari semenjak telur sampai imago menghasilkan telur.

2. Lama hidup imago(hari)

Pengamatan dilakukan dengan cara menghitung lama waktu yang dibutuhkan imago betina dan jantan mulai dari tahap awal imago sampai mati.

3. Nisbah kelamin (\%)
Pengamatan dilakukan dengan cara menghitung jumlah imago jantan dan betina.

4. Jumlah keturunan selama hidup (ekor)

Pengamatan dilakukan dengan cara menghitung jumlah keturunan yang dihasilkan individu imago betina selama hidup.

5. Masa pra ovoposisi, ovoposisi dan pasca ovoposisi (hari)

Pengamatan dilakukan dengan cara menghitung lama waktu yang dibutuhkan imago betina pada masa sebelum bertelur, meletakkan telur serta masa setelah bertelur.

\section{Analisis Data}

Data yang diperoleh pada saat penelitian berdasarkan variabel penelitian berupa siklus hidup, lama hidup imago, nisbah kelamin, jumlah keturunan selama hidup, masa praoviposisi, oviposisi dan pascaoviposisi, dicatat kemudianditabulasi lalu dideskripsikan.

\section{HASIL DAN PEMBAHASAN}

\section{Siklus Hidup Paracoccus marginatus}

Pengamatan menghasilkan data kehidupan individu kutu putih pepaya Paracoccus marginatus pada tanaman pepaya. Individu betina dan jantan $P$. marginatus mengalami tahapan perkembangan hidup yang berbeda. Individu betina mengalami metamorfosis Paurometabola (metamorfosis bertahap), yaitu terdiri dari stadium telur selama 6 hari, stadium nimfa selama 10 hari yang terdiri dari instar pertama hingga ketiga dan stadium imago yang tidak memiliki sayap selama 11 hari yang terdiri dari masa prapeneluran, peneluran dan pascapeneluran. Individu jantan mengalami metamorfosis holometabola 
(metamorfosis sempurna), yaitu terdiri dari stadium telur selama 6 hari, stadium naiad selama 17 hari yang terdiri dari instar pertama, instar kedua, instar ketiga yang disebut prapupa dan instar keempat yang disebut pupa, kemudian stadium imago yang memiliki sepasang sayap selama 3 hari.Setiap pergantian stadium ditandai dengan pergantian kulit yang diketahui dengan melihat sisa pergantian kulit (eksuvia) P. marginatus yang melekat pada permukaan daun.

$$
\text { Stadium telur } P \text {. }
$$

marginatusberwarna kuning kehijauan, berada di dalam kantung telur (ovisac), dan keseluruhan telur ditutupi oleh lapisan lilin berwarna putih. Kantung telur berkembang di bawah tubuh imago betina dan panjangnya terus berkembang hingga mencapai 3-4 kali panjang tubuh imago. Setelah telur menetas, instar pertama (crawler) yang merupakan fase paling aktif bergerak mencari makan.Nimfa instar berikutnya terutama imago betina cenderung menetap dan tidak aktif bergerak. Pada fase ini, jenis kelamin $P$. marginatus belum dapat dibedakan dan berukuran sangat kecil.

Setelah sekitar 4 hari, crawler berganti kulit dan disebut nimfa/naiad instar kedua.Pada fase ini, jenis kelamin $P$. marginatus sudah dapat dibedakan. Individu betina memiliki tubuh berwarna kuning sedangkan individu jantan memiliki tubuh berwarna merah muda.Lama stadium ini rata-rata 4 hari.

Pada fase nimfa instar ketiga, individu betina memiliki ukuran tubuh lebih besar dibandingkan dengan jantan dan merupakan stadium nimfa paling akhir sebelum menjadi imago dengan lama stadium rata-rata 8 hari.Sedangkan fase naiad instar tiga pada individu jantan merupakan fase prapupa dengan lama stadium rata-rata 3 hari. Setelah itu pada individu jantan merupakan fase instar empat berbentuk pupa yang ditutupi benang-benang lilin berwarna putih. Fase ini berlangsung selama 5 hari.

Pada penelitian ini, rata-rata siklus hidup individu betina $P$. marginatus, yaitu saat telur mulai diletakkan hingga imago betina ini mati adalah selama 27 hari dan siklus hidup individu jantan, yaitu saat telur mulai diletakkan hingga imago jantan ini mati adalah selama 26 hari (Tabe1).

\begin{tabular}{lcc} 
Tabel 1 Siklus & $\begin{array}{c}\text { hidup } \\
\text { marginatus } \\
\text { pepaya }\end{array}$ & $\begin{array}{c}\text { Paracoccus } \\
\text { panaman }\end{array}$ \\
\hline \multicolumn{1}{c}{ Stadium (hari) } & Betina & Jantan \\
\hline Telur & 6 & 6 \\
Nimfa/Naiad & 10 & 17 \\
Imago & 11 & 3 \\
Prapeneluran & 4 & \\
Peneluran & 6 & - \\
Pascapeneluran & 1 & \\
Siklus hidup & 27 & 26 \\
\hline
\end{tabular}

\section{Lama Hidup ImagoP. marginatus}

Rata-rata lama hidup stadium imago betina $P$. marginatus pada penelitian ini adalah selama 11' hari dan lama hidup imago jantan adalah 3 hari. Lama hidup stadium imago jantan umumnya lebih singkat dibandingkan lama hidup stadium imago betina.Imago betina memakan daun pepaya sedangkan imago jantan memakan nektar. Hal tersebut dikarenakan imago jantan mengalami perubahan struktur biologi dari naiad menjadi imago, tapi pada penelitian ini imago jantantidak diberikan makanan, sehingga menjadi salah satu penyebab pendeknya umur pada fase tersebut. Pada penelitian Amaresekareet al., (2008), lama hidup stadium imago betina dan jantan, berturut-turut adalah 21 hari dan 2 
hari. Bila dibandingkan dengan penelitian Amaresekareet al., (2008), terlihat bahwa lama hidup imago betina $P$. marginatus pada tanaman pepaya dalam penelitian ini lebih singkat. Perbedaan ini tidak terlepas dari perbedaan nutrisi dari tanaman inang $P$. marginatus tersebut dan selain itu pengaruh suhu dan perbedaan kelembaban lingkungan tempat penelitian dimana pada penelitian ini suhu rata-rata $30{ }^{\circ} \mathrm{C}$ dan kelembaban $74 \%$ sedangkan pada penelitian Amarasekareet al., suhu lingkungan dijaga sekitar $27{ }^{\circ} \mathrm{C}$ dan kelembaban $65 \%$.

Stadium imago betina memiliki tubuh berbentuk oval berwarna kuning yang ditutupi oleh lilin berwarna putih dan mengeluarkan embun madu. Stadium imago betina mirip dengan stadium nimfa, namun ukurannya lebih besar dan lebar. Pada stadium imago jantan, tubuh imago berwarna merah muda kecoklatan dan memiliki sepasang sayap, serta aktif terbang di sekitar pertanaman mencari imago betina.

\section{Nisbah Kelamin $P$. marginatus}

Nisbah kelamin imago jantan dan imago betina $P$. marginatuspada tanamanpepaya adalah 10 imago betina banding 2 imago jantan atau $9: 1$.Dengan persentase imago betina adalah $85 \%$ dari jumlah populasi. Pada penelitian Amaresekareet al., (2008), perbandingan imago betina pada empat tanaman inang adalah sekitar $53 \quad \%$ hingga $59 \%$ (Acalypha: $53 \%$, Hibiskus: $53 \%$, Phartenium 53\% dan Plumeria $59 \%$ ). Faktor fisik dan kimiawi tanaman dapat mempengaruhi karakteristik populasi serangga. Jumlah imago betina yang lebih banyak daripada imago jantan dapat menimbulkan masalah jika serangga tersebut bersifat merugikan. Hal ini terjadi karena, perkembangan populasi di suatu habitat ditentukan oleh banyaknya imago betina, artinya semakin tinggi perbandingan seks rasio individu betina maka populasi akan semakin cepat meningkat.Faktor penentu jenis kelamin salah satunya yaitu ketersediaan pakan. Imago betina memiliki naluri untuk mendeteksi ketersediaan pakan bagi kelangsungan hidup keturunannya. Pada penelitian ini pakan yang tersedia hanya berupa tanaman pepaya sehingga mendukung bagi pertumbuhan individu betina khususnya imago, sedangkan nektar yang dibutuhkan imago jantan tidak tersedia. Hal tersebut mengakibatkan imago betina lebih banyak menghasilkan keturunan individu betina dibandingkan individu jantan.

\section{Jumlah Keturunan Imago Betina $P$. marginatusSelama Hidup}

Dari hasil penelitian, jumlah ratarata telur yang diletakkan atau fekunditas imago betina $P$. marginatus adalah 370 butir per induk.Pada penelitian Amaresekareet al., (2008), jumlah telur yang diletakkan pada tanaman Plumeria, Parthenium, Acalypha dan Hibiscus, berturut-turut adalah 186; 230; 235; dan 244 butir per induk. Menurut Amaresekareet al., (2008), perbedaan siklus hidup $P$. marginatus pada beberapa tanaman inang dapat dikarenakan faktor nutrisi, senyawa alelokimiawi dan struktur fisik daun tanaman inang. Spesies tanaman yang berbeda menyediakan kualitas nutrisi dan unsur pokok kimia yang berbeda, sehingga hal ini dapat mempengaruhi karakteristik suatu populasi terutama terhadap perkembangan, tingkat reproduksi dan ketahanan serangga tersebut. 
Masa Praoviposisi, Oviposisi dan Pascaoviposisi

Setiap organisme memiliki variasi jangka hidup yang terbatas akibat berbagai faktor, sehingga dapat ditentukan karakteristik kelangsungan hidup organisme di dalam suatu populasi.Lama masa Praoviposisi, Oviposisidan Pascaoviposisi disajikan pada gambar 1.

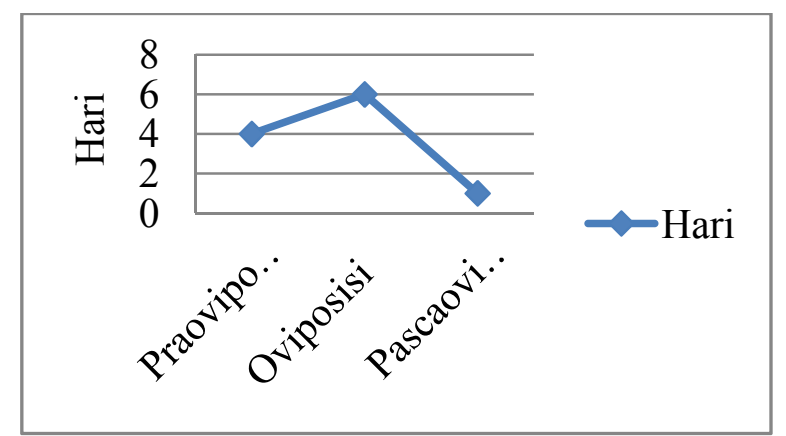

Gambar 1 Kurva masa Praoviposisi, Oviposisi dan Pascaoviposisipada stadium marginatus telur imago betina $P$.

Pada penelitian ini, rata-rata masa prapeneluran adalah 4 hari, masa peneluran selama 6 hari dan masa pasca peneluran selama 1 hari. Setelah masa peneluran, rata-rata keperidian P.marginatus adalah 350 per induk.Pada penelitian Amarasekereet al., (2008), rata-rata masa prapeneluran, masa peneluranP.marginatus pada empat tanaman inang yang berbeda, berturutturut adalah 6 dan 11 hari. Pada tanaman inang pepaya, masa prapeneluran dan masa peneluran betina dewasa $P$. marginatus lebih singkat dibandingkan pada tanaman inang hasil penelitian Amarasekereet al., (2008) sedangkan masa pasca peneluran pada penelitian Polat et al., (2008) selama 3 hari.
Memasuki masa peneluran imago betina membentuk kantung telur yang terbuat dari benang-benang lilin yang sangat lengket dan mudah melekat pada permukaan daun bagian bawah kemudian telur diletakkan dalam kantung telur tersebut.Kantung telur menempel pada bagian ventral ujung abdomen imago betina.Untuk pengamatan peletakan telur perhari, dilakukan pengamatan menggunakan asumsi bahwa nimfa yang telah menetas setiap harinya dihitung sebagai telur yang diletakkan per hari. Hal ini dilakukan karena telur diletakkan dalam kantung telur yang tidak memungkinkan apabila kantung telur dibuka.

\section{SIMPULAN}

$\begin{array}{lcr} & \text { Berdasarkan hasil penelitian dapat } \\ \text { diambil } & \text { kesimpulan bahwa } & \text { rata-rata } \\ \text { siklus } & \text { hidup } & \text { individu }\end{array}$
betinaParacoccusmarginatus adalah 27 hari dan siklus hidup individu jantan adalah 26 hari.Rata-rata stadium telur selama 6 hari, nimfa betina selama 10 hari. Naiad jantan selama 17 hari, imago betina selama 11 hari, dan imago jantan selama 3 hari.Rata-rata fekunditas P.marginatus adalah 370 butir per induk dan rata-rata keperidian adalah 350 butir per induk. Nisbah kelamin kutu putih pepaya P.marginatuspada tanaman pepaya adalah $9: 1$. Rata-rata masa prapeneluran adalah 4 hari, masa peneluran selama 6 hari dan masa pasca peneluran selama 1 hari. Setelah masa peneluran, rata-rata keperidian P.marginatus adalah 350 per induk.

\section{UCAPAN TERIMA KASIH}

Peneliti menyampaikan ucapan limpah terimakasih kepada sumua pihak 
atas dukungan dalam pengembangan sehingga penelitian ini bisa berjalan dengan baik.

\section{DAFTAR PUSTAKA}

Amarasekare KG, Chong JH, Epsky ND, Manion CM. 2009. Effect of Temperature on The Life History of The Mealybug Paracoccus marginatus (Hemiptera: Pseudococcidae) [Abstrak]. J Econ Entomol Vol.101 hlm: 798-804.

Amarasekare $\mathrm{KG}$, Mannion $\mathrm{CM}$ dan Osborne LS. 2008. Life History of Paracoccus marginatus (Hemiptera: Psudococcidae) on Four Host Plant Spesies Under Laboratory Condition. J Environ. Entomol. Vol 37(3): 630-635.

Anes N.S.,Tulung M.,Mamahit J.M.E. 2012. Penyebaran dan Tingkat Serangan Kutu Putih Pepaya di Sulawesi Utara. Eugenia. Vol 18 (1): $16-21$

Herlinda S.,Darmawan K.A., Firmansyah.,Adam T.,Chandra I., Thalib R. 2012. Bioesai Bioinsektisida Beauveria bassiana dari Sumatera Selatan Terhadap Kutu Putih Pepaya, Paracoccus marginatus Williams dan Granara De Willink (Hemiptera: Pseudococcidae). Jurnal Entimologi Indonesia. Vol 9 (2): 81-87

Perdana A.V. 2012. Populasi dan Serangan Hama Kutu Putih (Paracoccus marginatus William dan Granara the Willink) Pada Tanaman Pepaya. Fakultas Pertanian-Universitas Jember.
Pramayudi N.,Oktarina H. 2012. Biologi Hama Kutu Putih Pepaya (Paracoccus marginatus) Pada Tanaman Pepaya. J Floratek 7: 3244

Pu'u Yustina, Wahyuni Sri. 2011. Penyebaran Hama Kutu Putih Pepaya Paracoccus marginatus Williams \& Granara de Willink (Hemiptera: Pseudococcidae) Pada Berbagai Tanaman Inang Di Kabupaten Ende. Ende: Program Studi Agroteknologi Fakultas Pertanian Universitas Flores.

Sobir, 2009. Sukses Bertanam Pepaya Unggul Kualitas Supermarket. http://www.belbuk.com disidir (tgl 01 Februari 2012). 